Article

\title{
Relations between Land Tenure Security and Agricultural Productivity: Exploring the Effect of Land Registration
}

\author{
Uwacu Alban Singirankabo*(D) and Maurits Willem Ertsen \\ Water Management Department, Delft University of Technology, 2628 CN Delft, The Netherlands; \\ m.w.ertsen@tudelft.nl \\ * Correspondence: u.a.singirankabo@tudelft.nl
}

Received: 1 April 2020; Accepted: 30 April 2020; Published: 2 May 2020

\begin{abstract}
This paper reviews the scholarly literature discussing the effect(s) of land registration on the relations between land tenure security and agricultural productivity. Using 85 studies, the paper focuses on the regular claim that land registration's facilitation of formal documents-based land dealings leads to investment in a more productive agriculture. The paper shows that this claim is problematic for three reasons. First, most studies offer no empirical evidence to support the claim on the above-mentioned effect. Second, there are suggestions that land registration can actually threaten 'de facto' tenure security or even lead to insecurity of tenure. Third, the gendered realization of land registration and security may lead to uneven distribution of costs and benefits, but these effects are often ignored. Next to suggesting the importance of land information updating and the efficiency of local land management institutions, this paper also finds that more research with a combined locally-set approach is needed to better understand any relation(s) between land tenure security and agricultural productivity.
\end{abstract}

Keywords: land tenure security; agricultural productivity; land registration

\section{Introduction}

Securing land tenure has regularly been prioritised by policy-makers to ensure and develop more productive agriculture [1-9]. In this journey, land registration has been considered the main intervention and starting point to ensure that tenure is formally recognised and protected against illegal claims of land rights. The International Federation of Surveyors (FIG) defines land registration as the official recording of legally recognized interests in land [10]. The usual proof of formal registration is a legal document ascertaining that the rights held on a plot of land are provided by the law against any third party. Hence, adopting the FAO [11] definition, this paper considers land tenure security to be the certainty that a person's rights to land is and will be recognised by others and protected in cases of specific challenges. Nonetheless, not all land registration programmes prove to secure land rights, nor instil improvement in agricultural productivity $[5,12,13]$. The effects of land registration on agricultural productivity are even more unclear, however, as this paper will show.

Land tenure and land titles would have featured prominently in early agricultural economies [14,15], but traditionally, land tenure security and agricultural productivity have been two separate areas of research. The link between land tenure security and agricultural productivity is therefore a relatively new subject $[6,16]$. Although recent decades have seen many publications research on the subject, the relation between land tenure and production continues to be conceptually described rather than operationally proven [17]. Furthermore, the relation itself is still open for debate. Initially, Hanstad [14] argued that individual and secure land tenure rights are vital components of a productive 
agricultural sector, which is crucial to poverty alleviation and economic growth. However, Holden and Ghebru [6] found that, although the links between tenure security and agricultural productivity are of primary interest, the reverse link can also potentially be important. The authors argue that, given that tenure security is endogenous, a positive correlation between investment and land tenure security could occur, because people invest to become more tenure secure. Empirical evidence to confirm the proposed direct relation, as already noticed early on in the debate [18], remains scant.

The purpose of this paper is therefore to assess in considerable detail how the relations between land registration, land tenure security, and agricultural productivity are discussed in the scholarly literature. We identify the extent of and evidence for those relations, and indicate plausible needs for further research on the subject. The paper discusses the claim, found implicitly or explicitly in most of the literature, that land registration would realize land tenure security, which would allow-envisaging their tenure sustainably-farmers to use their land plots as collateral to get loans from the bank and invest in new farming systems and technology to increase the yield at a lower cost of production. In fact, holding legal proof of land rights is claimed to stimulate farmers' initiative to invest in a more productive agriculture.

We provide three (sets of) remarks that suggest that this major claim is less straightforward than often presented.

1. A reasonable number of research work found quite low effects at most or no evidence at all to prove such relations, especially in the customary tenure regime in Sub-Saharan Africa.

2. Some studies suggest that land registrations can threaten 'de facto' tenure security or even lead to insecurity of tenure which affects agricultural productivity.

3. Whereas women land rights and their role in agriculture production is discussed, the literature is relatively silent on specifying how costs and benefits of land registration are distributed over male and female farmers.

Furthermore, we explore the evolution of research on the relations between land registration and agricultural productivity. Primarily, since the early 1980s, transactions over land have been considered as enabler of any possible effect of formalising land tenure on agricultural productivity. Apart from the 'legal papers-loan-investment' theory referred to above, the literature argues that land registration's legal outcome facilitates land transactions by supporting the possibility to sell, buy and lease land in a more secure way $[2,6,19]$. These transactions may or may not reach out to investments in agriculture. As the research amassed, a new aspect emerged: the importance of local settings.

In addition to the economic aspect, recent literature underlines the role of locally formed institutions to strengthen the relations we discuss [1,20]. However, this new aspect still lacks field evidence, since a number of the reviewed texts are synthesis and review papers themselves. In general, the documents reviewed for this paper pay less attention to the process of land registration itself, instead prioritising the resulting land tenure security in their analysis. We argue that land registration programmes and procedures to implement these programmes are among the major reasons of failure to achieve stronger land tenure security. Thus, land registration and land information updating processes should be part of studies on land tenure and productivity.

Below, we will describe how we selected the 85 studies that we used in our analysis, followed by a discussion on the main claim discussed in this paper and depicted above. After discussing the three categories of remarks and the importance of the registration process, we conclude with implications of the results.

\section{Materials and Methods}

This study reviews literature to identify the effects of land registration on agricultural productivity and determines any gaps yet to fill in. Given the review nature of this paper, we adopted the review methods used in the research paper written by Simbizi, Bennett [21]. A systematic search of literature was conducted to highlight current arguments and research findings on those effects. The same 
literature was subsequently used to determine gaps in the literature on the subject. The methods used to search and review the literature are described in [22]. The review followed five stages: (1) Problem formulation, (2) literature search, (3) data quality evaluation, (4) analysis and interpretation, and (5) presentation of results [22].

\subsection{Search Strategy}

The literature search was computer-based. We developed a strategy using a set of key words and other advanced search options such as Boolean operations (and, or) and truncation. That allowed to formulate the following search query:

(("land registration" OR "land certification" OR "land tenure regulari" ${ }^{*}$ " OR "land reform" OR "land tenure" OR "land tenure security" OR "customary land tenure" OR "land right" OR "land governance" OR "land information") AND ("agricultur" producti*" OR "agricultur" transform" $O R$ "investment in agriculture*" OR "Fertilizer")).

*For inclusion criteria see Appendix A, Table A1

The search query and a number of other combinations of its composing key words were used on different search databases. The search comprised databases like SCOPUS, Web of Science, Elsevier, GEOBASE, Springer Link, AJOL, JSTOR and libraries to which we are subscribed were used. In addition, we utilised available resources on the World Wide Web.

The preliminary search attempts generated many resources that were not all useful. Then, we set boundaries of this review. Three types of documents were considered for the review: (1) Peer-reviewed journal articles, (2) books, (3) technical reports (grey literature) published by international organisations. Only resources written in English, addressing the relations between land registration, land tenure security and agricultural productivity, were selected for the review. A priori methodological quality judgment criteria [22] were applied to exclude studies whose methodological quality was difficult to assess in a systematic way (mainly conference papers and national reports).

The review period was set from 1980-2019, bearing in mind that the year 1980 arguably corresponds to the recent history and development of evolutionary theory of property rights [23-25]. This year marked the start of heated debates on land reform in many countries with developing economies. A data extraction form was used to systematically fill in the following information: (1) Type of document, (2) the title, (3) field of the study, (4) country/sub-region/region, (5) meaning, definition or views of the effects of land registration on agricultural productivity (6) online library where the document had been accessed, (7) reference and (8) search date. A critical descriptive analysis was conducted using the technique of topic mapping [26]. After exploring 1940 studies, we considered 85 for this paper (Figure 1 and Appendix A, Table A2). Of these 85 studies, 79 are journal articles, 2 technical reports and 4 books.

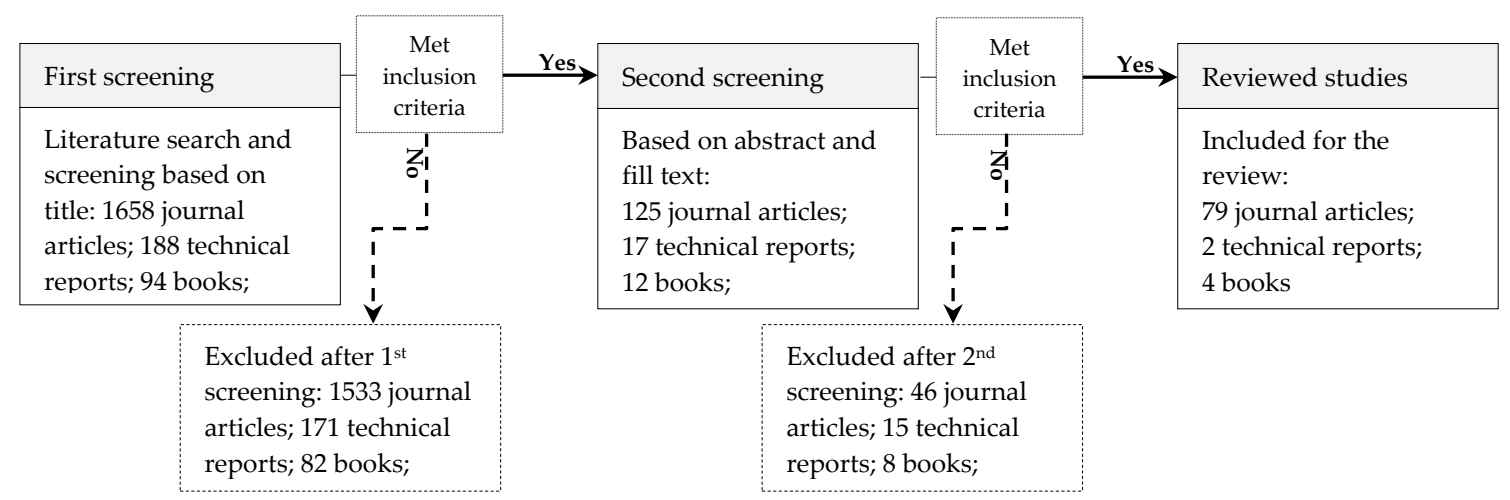

Figure 1. Flow diagram for quantitative search and screening. 
Of the 85 studies we reviewed, 45 discussed issues in 22 countries with developing economies (Figure 2). The other 40 consist of regional and international studies. The distribution of reviewed studies per year of publication illustrates their gradual increase in numbers from 1980's to the recent years (Figure 3).

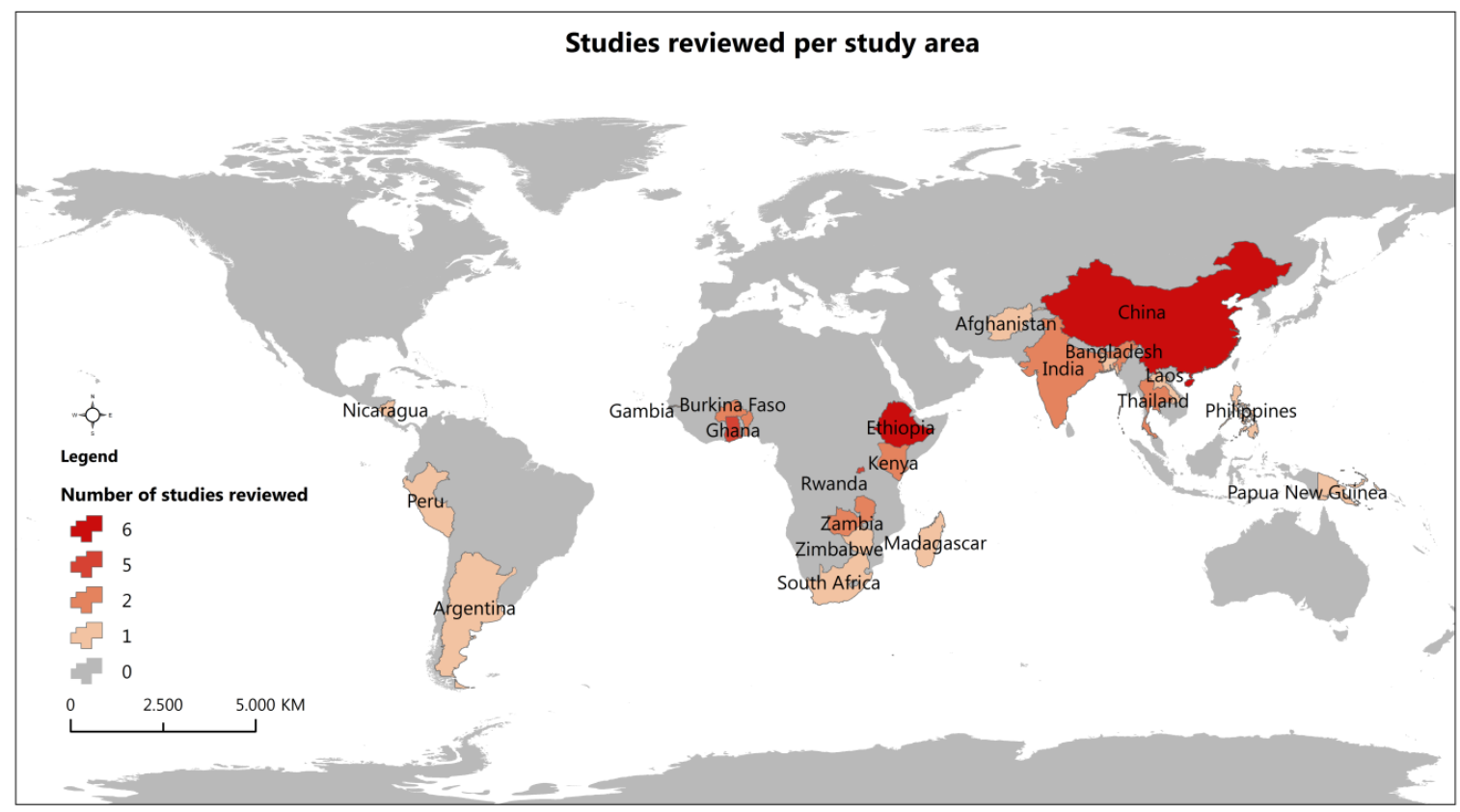

Figure 2. Distribution of studies reviewed per country.

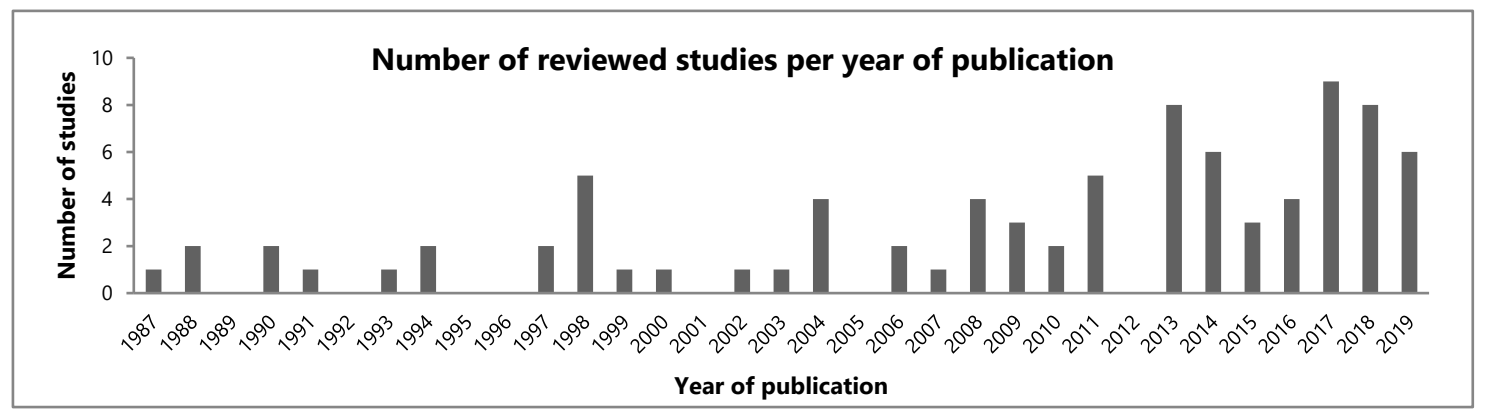

Figure 3. Distribution of reviewed studies by year of publication.

\subsection{Assessment of the Content of the Reviewed Studies}

The 85 texts discussed in this paper cover a wide range of topics concerning land registration, land reform, land tenure activities and outcomes, as well as agricultural productivity. The review followed a narrative synthesis approach [27]. We identified and assessed the main claims made concerning the effect of land registration on the relations between land tenure security and agricultural productivity. This was done by categorizing the evidence found in the studies we reviewed (Table 1). The evidence with considerable coverage is discussed in detail in Section 4.

In general, the research work that we reviewed is mostly based on literature review and secondary data sources. When primary data are mobilized, the methodological approaches vary, although they tend to converge to a combination of econometric modelling and statistical analysis. The dominant methods are: (1) Stochastic Production Frontier (SPF) models using data from household panel surveys [4,5]. (2) Conditional Maximum Likelihood (CML) [2]. (3) Two-step conditional maximum likelihood (2SCML) techniques: linear probability regression for the discrete variable and probit regression $[3,28]$. 
Table 1. Assessment of the evidence on the effect of land registration on the relations between land tenure security and agricultural productivity.

\begin{tabular}{|c|c|c|}
\hline Category & Rationale & Reviewed Studies \% \\
\hline \multirow{6}{*}{$\begin{array}{l}\text { Strong } \\
\text { evidence }\end{array}$} & $\begin{array}{l}\text { Correlation between land tenure security and agricultural productivity calculated } \\
\text { before and after land registration using panel data about: }\end{array}$ & \multirow{6}{*}{54} \\
\hline & - $\quad$ Cases of conflicts over land & \\
\hline & - Loans used to invest in agricultural activities (fertilisers, seeds, irrigation) & \\
\hline & - Investment in agriculture & \\
\hline & Farm harvest; & \\
\hline & $\begin{array}{l}\text { Farm technical efficiency following land registration; } \\
\text { Improvements in legal land (rights) transactions. }\end{array}$ & \\
\hline $\begin{array}{l}\text { Weak } \\
\text { evidence }\end{array}$ & $\begin{array}{l}\text { The relations between land tenure security and agricultural productivity may exist, } \\
\text { but they are difficult to measure given that land registration alone cannot have an } \\
\text { effect; } \\
\text { The effect exists indirectly through enabling design and implementation of } \\
\text { developmental strategies such as taxation, land use plan, land consolidation, } \\
\text { agricultural transformation. }\end{array}$ & 34 \\
\hline No evidence & $\begin{array}{l}\text { This category contains the studies claiming, on the contrary, that land registration } \\
\text { threatens the long-term established de facto tenure security and agricultural } \\
\text { productivity. }\end{array}$ & 12 \\
\hline
\end{tabular}

\section{Land Registration, Tenure Security and Investment(s)}

In the last four decades, land tenure regularisation gained importance in the literature on agricultural productivity. The underlying main claim stipulates that when their land rights are legally protected, farmers invest to make their agricultural system more productive. Overall, 54 per cent of our 85 studies claimed so. However, whether or not legally recognised land tenure has an impact on agricultural productivity, or even to what extent that form of tenure contributes to more productive agriculture, remains uncertain [29-32]. Furthermore, research underlines the particularity of growing agrarian economies of developing countries [33,34]. These countries are still working to secure land rights, while pursuing an agriculture transformation phase, transiting from subsistence to market-oriented production.

As the starting point of land tenure regularisation, land registration is assumed to support land dealings $[10,35]$. In the first place, the information gathered through registration forms part of a system, that may be open to renters, sellers and buyers of land (rights), and so provide increased transparency on the land market. Second, land registration and the resulting legal framework may guarantee trust when accessing loans from the banks. Given that land and agriculture constitute the main source of income in rural areas of developing economies, the loans may be invested in agricultural activities and associated businesses. Another effect underscored and contested in the literature, is the ability of legal tenure to improve perceived tenure security $[30,36,37]$.

Early literature suggests that the guarantee assured by a tenure-registration document improves the security of tenure. The effects of secured ownership on both the availability of credit and investment incentives, imply that farmers without secure ownership will have lower investments and land improvements, use of variable inputs, and productivity per unit of land [38-40]. For example, Feder, Onchan [38]'s work in Thailand highlighted first evidence of the link between tenure security and agricultural productivity. They distinguished three effects. First, the greater tenure security increased farmers' demand for improvements by increasing their confidence that they would benefit from such improvements over the long-term. Second, tenure security increased the supply of formal credit through the creation of tradable collaterals. Finally, both effects resulted in higher short-term investments in inputs and long-term investments in productive and land-conservation technologies, leading to higher sustainable production $[38,39,41]$.

Several studies have focused on the effect of legal ownership on farm output or income. In a study conducted in Costa Rica, for one province a positive correlation of 0.53 was found between income per unit of land and security of ownership. In another province, however, the correlation was negative, 
although quite weak (-0.07) [40]. A study dealing with the Brazilian state of Maranhao concluded that granting full legal ownership to squatters and undocumented occupiers would increase their income by 200 percent. The same study reported that income levels of titled farmers were two times higher than those of untitled farmers, when the amount of land owned was held constant [40].

More recent research work explores the benefits of land registration projects on a longer time span, trying to demonstrate the link with land tenure security and agriculture productivity [42,43]. A study on Benin stressed that land certification has improved tenure security and stimulated investment in agriculture [44]. The study concluded that increasing tenure security, especially in the initial stages of formalization, can positively affect investment decisions. Hence, according to the authors, 'improved tenure security from program demarcation activities leads households to shift their investment decisions from subsistence crops to long-term and perennial cash crops' [44]. However, the same study suggested that further research was needed to complete the picture and establish the causal effect of a full formalization of property rights, up to the delivery of a transferable title.

Using panel data from rural representative households surveys in Burkina Faso, Bambio and Bouayad Agha [2] argue that stronger land rights increase land-attached investment. In reverse, land investment has positive and negative effects on stronger and weaker land rights, respectively, in rural Burkina Faso. However, investment in land with unclear rights increases land conflict [45]. The authors also found that assets, immigration, and literacy have positive effects on land investment, which suggests that more than land tenure alone is at stake in improving agricultural production. Moreover, the authors imply that a gain of efficiency can be achieved by combining practices in land tenure and investment. Formal land rights is only applicable to $4 \%$ of agricultural land in Burkina Faso [2].

In general, there is widespread belief among development economists, that land registration has a bearing on agricultural productivity in developing countries. Land registration, it is argued, increases credit use through greater incentives for investment in agriculture and reduced incidences of land disputes [46,47]. The resulting legal tenure also would influence investments in fixed inputs such as machinery, which are important for enhancing productivity. Among the studies we reviewed, 34 per cent found weak evidence to claim so. Below, we provide three (sets of) remarks that suggest why the major claim is less straightforward than often presented. First, we discuss the actual evidence provided to prove such relations. Second, we discuss how land registration could threaten 'de facto' tenure security. Third, we show that the literature is relatively silent to specify the gendered nature of land registration and tenure.

\section{Evidence for Relations between Land Registration and Agricultural Productivity}

In the 1990s, a number of studies on African settings have formally tested the nature and strength of the relation between tenure security and agricultural performance (e.g., [48] in Gambia; [39] in Ghana, Kenya and Rwanda; and [49] in Kenya). With few exceptions, land rights were not found to be a significant factor in determining whether or not farmers made land-improving investments, used yield-enhancing inputs, accessed credit, or improved the productivity of land. A study that included Ghana, Kenya and Rwanda, found 'no relationship between cross-sectional variations in land rights and productivity' [50]. The authors argue that the most pronounced relationships were found in Rwanda, where the right to bequeath was a significant determinant of some types of land improvements. Rwandese parcels that could not be bequeathed, were mostly rented or borrowed under short-term arrangements. As such, the tenant had little incentive to invest. In addition, the use of formal credit did not appear to be related significantly to land rights. In Kenya, no significant relationship between crop yield and land rights was found. The study found, that the presence of land titles did not affect yields in any significant way either. These results are contrary to the widely held notion that security of tenure and titling leads to higher yields. It is notable that the study focused largely on smallholders with an average land parcel of between 0.53 ha to 4.1 ha. These results questioned the need for ambitious land registration and titling programs at that time [13]. 
A recent literature review study based on the analysis of 59 studies found strong evidence for positive effects of land tenure security on productive and environmentally beneficial agricultural investments, as well as on female empowerment, but a lack of support for links with productivity, access to credit and income [1]. Overall, the review suggests that more evidence still needs to be generated on the land tenure security interventions as there is much learning to be done. The most complete evidence is likely to be generated through a combination of quantitative and qualitative approaches, with quantitative approaches taking the most rigorous approach possible, particularly randomised control trials, to assess impact and qualitative approaches that seek to identify key contextual factors to determine that impact.

Li and Zhang [51] argued that generally in Africa, land tenure reform has made a great contribution to improving agricultural productivity and can provide an effective long-term solution to food security. However, in sub-Saharan Africa, where land under customary tenure is usually neither registered nor accepted as tradable collateral, the authors hardly detected such contributions. Lawry, Samii [52] argue that most farms in sub-Saharan Africa are held under customary tenure arrangements, which generally provide long-term tenure security to qualified members of land-holding families, groups or communities. Their study underlines the existence of a level of pre-existing tenure security provided by customary tenure without formalization. Therefore, titling may not operate easily in areas where customary tenure exists. This suggests that titling programmes are suitable mainly for households in stable employment, who can afford to service the market-based interest rates for accessing formal credit, along with meeting other terms and conditions, such as collateral and deposits or down-payments [53,54]. This has been the case in Uganda, for which Kamusiime, Rugadya [55] claim that the transformation of customary tenure embodied in systematic demarcation, was expected to provide an opportunity for farm households to rid themselves of poverty, but actually created more tenure insecurity. The authors conclude that neo-liberal policies, emphasising market-based land reforms, effectively put pressure on customary tenure.

As mentioned above as well, however, many authors found that the key relationship discussed in this paper is not automatic and other effects need to be taken into account [29,56-62]. A study on agricultural productivity impacts of formal and informal land rights in Madagascar found that tenure insecurity would negatively influence the relation between the right to lease out land and agricultural productivity [63]. These empirical results suggest that formal land rights (i.e., land titles) have no impact on productivity, but that informal land rights (i.e., landowners' subjective perceptions of what they can and cannot do with their plots) have heterogeneous impacts on productivity. Törhönen [37] suggests that a successful land reform program supposes a workable land administration, built upon good governance, appropriate resources, cultural sensitivity, equity, quality and commitment. This implies that land tenure structures are secure, corruption-free, flexible and all-inclusive. Lack of transparency of public administration leads to a situation, where farmers are reluctant to use the title deed as collateral, and formal credit institutions do not put much faith in the title deed [49].

Other studies cast doubt on the existence of a systematic influence of land tenure security on investment. [64] conclude that the traditional village order, where it exists, provides the basic land rights required to stimulate small-scale investment. [54] suggest that in Nicaragua, titling can have a positive effect, but that the legal validity and official recognition of the titles issued appears to be of great importance. For North-East Ghana, [65] claims that a policy focus on enhancing tenure security may fail to lead to increased agricultural production, if similar focus is denied to non-tenurial factors, including lack of finance, poor soil fertility, inadequate and unreliable rainfall, pests and diseases, inadequate farmlands, bush burning and excessive tree cutting. The report of the Economic Commission for Africa's Sustainable Development Division (SDD) on Land Tenure Systems and their Impacts on Food Security highlights similar claims [66]. 


\section{Insecurity of Tenure Threatening Productivity}

Numerous studies conducted on tenure and how it affects agricultural productivity, suggested tenure's ability to stimulate investment in agriculture. However, increasing numbers of current research work suggest that - at least in Africa - the opposite may prevail. On the one hand, the complexity emanates from the existence of various types of land tenure systems. It is difficult to comprehend the manner in which land tenure issues influence farmer incentives in a mixed group of farmers who hold statutory and/or customary rights on lands [67]. Ege [12] argues that land registration failed to improve tenure security, land dealings and agricultural productivity in Ethiopia. The author distinguished three different rights in land tenure security: possession, renting and latent rights. Following land registration, rights of possession are believed to have improved, but the evidence remains weak and conflicting. Land rentals were expanding, but farmers were facing high tenure insecurity. The main problem, though, has been the latent rights, with great insecurity and increased conflict levels. The author found that, despite rapid economic development, there was considerable social malaise, a failing agricultural structure, and considerable pressure for land redistribution because of unresolved land tenure issues. In addition, given that purchase restrictions hardly exist, Ncube [67] argues that international organisations and governments have embarked on land purchases in Africa, exposing smallholder farmers to arbitrary land acquisitions.

An Indonesian case illustrates the complexity of the relations between land tenure security and agricultural productivity well. Using empirical material from 16 villages in Jambi province in Indonesia, Kunz, Hein [68] show that the outcomes of the state-led land reforms and land tenure formalization processes are imitated and translated into locally feasible actions. The authors refer to these translation processes as 'mimicry of the legal.' The authors found that, even though the government of Indonesia invested massive amounts of money to accelerate national land formalization processes, flexibility in regard to land use continues to be present, allowing for an exploitation of the landscape and accelerating the expansion of small-scale agriculture in the forest frontier areas of rural Indonesia [68,69].

A study on the link between land tenure security and technical efficiency in Northwest China and Bangladesh (Ma, Heerink [4] argues that the provision of land certificates to rural households had a negative impact on the technical efficiency of agricultural productivity under the prevailing factor market imperfections in the region. In the Philippines, despite the presence of formalised titles, a study found that the rental market remained ineffective for allocating land. In contrast, non-formalised tenure contracts used by farmers appeared to provide tenure security [5]. For Afghanistan, Murtazashvili and Murtazashvili [35] argue that the Community-Based Land Adjudication and Registration, or CBLAR, initiative is more appropriate than legal titling. More generally, the authors argue that CBLAR improves household land tenure security in post-conflict settings, when implemented in the appropriate context and with appropriate support from the state and international donors. Despite the promising approach, however, the success of these initiatives in improving household land tenure security is thought to depend on the quality of customary governance and on investment in public goods, such as roads, schools, lending institutions, administrative capacity of local governments, and forums to resolve disputes that overwhelm communities.

\section{Gender Considerations}

Our paper reviewed scholarly literature on the effect of land registration on the relations between land tenure security and agricultural productivity. Given that 14 of the reviewed studies discuss the particularity of gendered land tenure, we found it relevant to include this issue in our paper. However, the studies we reviewed rarely discuss how gendered land tenure relates to agricultural productivity. This link needs to be further explored in future research work.

Odhiambo [70] claims that unless the context is right, formalizing land tenure may exacerbate a given unequal situation in land ownership, while introducing new problems and challenges. When that happens, those who suffer the most are the poor, marginalized and vulnerable in society, including women and children, pastoralists and hunter-gatherers. Women land rights and their role in agriculture 
production feature in most of the literature dealing with land registration, land tenure security and agricultural productivity. Land tenure insecurity for women arises from rapid socioeconomic change, disrupting customary institutions, and from excessive government interference in customary tenure systems [66]. However, in the studies on the relations between the three issues central to our paper, what gendered relations in land tenure and agricultural production actually mean is less discussed, and if so, only very recently. Among the 85 studies we reviewed, only 14 looked into gender implications and particularities of positions and rights of women. This points to a scarcity of empirical evidence to assert how land tenure security of women is affected by land registration or how women tenure security contributes to agricultural productivity, let alone how the relations between their land tenure security and access to credit, technology adoption and agricultural productivity are shaped [2,71].

Inclusiveness to ensure access to land to unlock land tenure insecurity issues particularly for women and other underprivileged groups, is discussed more often [72], as it enables land users and farmers, who own land, to capture the expected socioeconomic benefits from their land. Formalising land tenure does not always seem to benefit women, however. The social, political and economic context in which formalization is implemented, is the key determinant of whether or not formalization succeeds in benefiting the target group and securing tenure [70].

Looking at the role of women in smallholder agriculture, the World Bank claims that men are usually the formal landowners in both traditional and modern land tenure systems. Less than 2 percent of African women have ownership rights to their land. Lack of official landownership reduces women's ability to access finance and other resources [73]. Plots held by women in polygamous households are perceived as less tenure secure [28]. Formal land titles, when they exist, appear to be usually assigned to men in both traditional and modern land tenure systems, even when women contribute significantly to agricultural production [71]. Han, Zhang [74] argue that the land tenure of Chinese rural women is subject to considerable discrimination and is highly insecure because of the greater risks involved compared to those faced by men. The authors call for policies facilitating legal land tenure security through the separation of women's individual tenure from the households in the issue process and ensuring their legal status as the co-owners of household contracted farmland [74].

Formal registration of women's land rights is claimed to be a key in solving women's land disputes and increasing their empowerment, but being entitled to land ownership does not necessarily mean women's land tenure is secure, an issue that has received little attention to date [74,75]. During land reform, women and other vulnerable groups encounter more conflicts and evictions than men. For Rwanda, [76] argue that the land tenure regularisation program carried in the period 2007-2013, did improve land access for legally married women (about $76 \%$ of married couples) and prompted better recording of inheritance rights without gender bias. The authors found that the program was associated with a very large impact on investment. They noted this effect particularly to be pronounced for female-headed households, suggesting that this group had suffered from high levels of tenure insecurity, which the program managed to reduce.

\section{Discussion and Conclusions}

The aim of this review paper was to determine and describe the gap in the scholarly literature discussing the effect of land registration on the relations between land tenure security and agricultural productivity. Our review highlights the growing volume of literature on tenure security since the 1980s. However, in many studies, those effects continue to be conceptually described rather than operationally proven. Many studies offer indirect effects, in terms of secondary data rather than direct field evidence. We found weaknesses in the methods and techniques used to collect and analyse data, as well as the types of data mobilised to study the effects. The use of representatives' data from local authorities and farmers cooperatives instead of from farmers themselves, may provide misleading results and hide the households' tenure and productivity realities. In addition, research has been conducted using case studies within countries, but generalising their findings seems difficult given the particularities of different local settings. 
Early research work revealed the importance of market settings and other economic processes at work in different countries to determine agricultural inputs and harvests in formal or informal land rights dealings. Later on, social elements like farmers' perceptions and farmers' groups started to gain relevance in studies conducted on land rights formalisation and agricultural productivity. Assessing local realities and locally-set institutions appear as crucial, when seeking to understand the effects of land registration on agricultural productivity. The clear heterogeneity in findings in the literature suggests that policy responses must pay attention to both local contexts and overarching macro and sectoral conditions, within which tenure systems operate. Deeds systems, where the possession of the deed is proof of ownership, may not work in countries with high rate of criminal activities, for example [20,65,68,75,77-84].

We demonstrated the contradicting arguments found in the literature concerning effects of land registration and updating on agricultural productivity. Land titles or related legal papers may have helped to obtain loans from banks, using land as collateral, to invest in agriculture. On the other hand, land certification may have contributed to increased tenure insecurity, with possible negative consequences for agricultural productivity. Some studies concluded that even when there is effectively a correlation, it is associated with many intervening factors altogether, which makes it difficult to claim that it is the isolated link itself that created favourable conditions. One intermediate and linking element standing out, and most highlighted in the literature, is 'land tenure security': the security of tenure guarantees perceptions of long-term tenure and stimulates farmers initiatives to sustain their agricultural activities, thus creating the enabling environment. At the same time, literature points at the need to keep the cadastre information updated to avoid future misleading of land information-based dealings and to construct belief in the tenure systems.

The processes and procedures of land registration and land information updating projects appear to play a crucial role. However, the difference between systematic and sporadic registration and the way each affect productivity, is often ignored in the literature. In addition, claims that changes in agricultural productivity are associated with formalising land rights would not be strong enough, if studies do not consider the tenure systems at work and the effectiveness of institutions involved. Land registration has been considered both in cases of first (land information) registration and for the continual land information updating. The main underlying assumption was, that when land is formally registered, farmers use their legal documents to seek loans, using land as collateral and invest in agriculture. It is clear, however, that land registration may affect productivity in more ways than just via the loans-investment process as described in most of the reviewed studies.

\section{Suggestions for New Research on Tenure, Security and Productivity}

In most literature, land registration is mentioned as affecting land tenure security, but studies that directly deal with the relations between land registration and agricultural productivity are absent. We found that the effect of the land registration process itself on land tenure security and agricultural productivity is an understudied topic. Hence, the process of land registration, including the methods and techniques used to demarcate, adjudicate and record land information, is not considered, while it may have a crucial impact on farmers' decisions and thus agricultural productivity. Some authors stress that before one can validly assert whether land registration will enhance investment and productivity, a more careful definition is needed of the concept of 'tenure security' itself. Factors besides land titles that bear on such security, must be identified [21]. Indeed, land registration is not simply a technical matter; it is a complex social intervention. Therefore, historically evolved social relations and circumstances must be considered to achieve the results of land titling that are desired. Recognizing this would be directly relevant to the design and evaluation of titling programmes $[68,70,85]$.

Several studies have emphasised the important role of land (tenure) institutions at all levels of the administration to streamline land-based productivity. Such streamlining is not always positive is argued for Rwanda by Pritchard [86], who concludes that simultaneous and aggressive implementation of registration and crop intensification has significantly reduced land tenure and food security of 
subsistence households. Land registration records information needs to be managed, using regulatory and institutional frameworks $[87,88]$. The research approaches we found in our review miss two important aspects to deal with registration issues. One is the role of an up-to-date land information registry to realize tenure security and land governance in general [89]. Second, especially in rural areas, researchers pay less attention to other factors interfering with tenure security, including developmental programs such as land taxation and land consolidation, as well as the important role of particular local traditions [1].

The methods that are used in most of the studies in our review cannot tackle the complexity of how land tenure systems affect productivity [90]. This suggests that there is need for a mixed methods approach utilizing experiments as well as randomisation, where feasible, in combination with increasing flows of spatial and time-series data from diverse sources. Household-farm panel data collected over long periods of time, combined with simulations, can also provide valuable insights about the relations.

This paper contributes to an understanding of the effect of land registration on the relations between land tenure security and agricultural productivity. From an intensive review of a broad set of literature related to land registration, land information updating and agricultural productivity, the paper provides a better understanding of those effects. From the literature, we find that formalising land rights appears to contribute to an increase in agricultural productivity only when it is combined with effective land and agriculture policy (among others) and when the implementing institutions are effective [88]. Future research needs to concentrate on examining these relations from a more operational basis, taking into account local social-economic and institutional patterns at work.

Author Contributions: This article is part of ongoing $\mathrm{PhD}$ research on 'the relations between land tenure security, agricultural productivity and food security in Rwanda'. U.A.S. (the PhD candidate), set up the structure and approach of the manuscript and he contributed to all sections under the guidance of M.W.E. who is the supervisor. The supervisor also contributed to the revision and editing of the whole manuscript. All authors have read and agreed to the published version of the manuscript.

Funding: This research received an external funding from the Netherlands Organization for International Cooperation in Higher Education (NUFFIC) through SEAD project, which stands for 'Strengthening Education for Agricultural Development' in Rwanda.

Acknowledgments: We acknowledge the NUFFIC/SEAD project.

Conflicts of Interest: The authors declare no conflict of interest.

\section{Appendix A}

Table A1. Inclusion criteria of studies reviewed.

\begin{tabular}{cc}
\hline Criteria & Rationale \\
\hline Inclusion criteria first screening &
\end{tabular}

1. Study deals with the relations between land tenure security (LTS) and agricultural productivity with a lean-to the effect of land registration, land certification, land titling, land reform, land tenure regularisation, land governance.

2. Study was published between 1980 and 2019 , using data collected within this period, and, if the study reviews other research work, that research work should have been conducted within this period.

- This is the scope of our study

- We found that the year 1980 arguably corresponds to the recent history and development of evolutionary theory of property rights

3. Considered for our review are peer reviewed journal articles, books and technical reports.

- $\quad$ This ensures a minimum quality level and avoids broadening the search to an unmanageable level. 
Table A1. Cont.

Inclusion criteria second screening

4. The study's abstract opens a clear path to explore the effect of land registration on the relations between land tenure security and agricultural productivity. For example, we assess if the study contains sufficient details for methodology to be assessed and results to be properly interpreted.

- This ensures a proper assessment of findings.

Table A2. List of studies reviewed.

\begin{tabular}{|c|c|c|c|}
\hline Reference & Focus of the Study/Title & Country/Sub-Region/Region & Category \\
\hline [18] & $\begin{array}{l}\text { Land Rights Systems and Agricultural Development in } \\
\text { Sub-Saharan Africa. }\end{array}$ & Sub-Saharan Africa & SE \\
\hline [38] & Land policies and farm productivity in Thailand. & Thailand & SE \\
\hline [85] & Land titling: conceptual, empirical and policy issues. & International study & WE \\
\hline [46] & $\begin{array}{l}\text { Land Tenure and Investment in African Agriculture: Theory } \\
\text { and Evidence. }\end{array}$ & Sub-Saharan Africa & SE \\
\hline [9] & $\begin{array}{l}\text { Land Registration in Africa: The Impact on Agricultural } \\
\text { Production. }\end{array}$ & Sub-Saharan Africa & WE \\
\hline [50] & $\begin{array}{l}\text { Indigenous Land Rights Systems in Sub-Saharan Africa: A } \\
\text { Constraint on Productivity? }\end{array}$ & Sub-Saharan Africa & SE \\
\hline [13] & $\begin{array}{l}\text { Productivity Effects Of Indigenous Land Tenure Systems In } \\
\text { Sub-Saharan Africa. }\end{array}$ & Sub-Saharan Africa & NE \\
\hline [39] & $\begin{array}{l}\text { Land tenure security and agricultural performance in Africa: } \\
\text { overview of research methodology. }\end{array}$ & Regional study & NE \\
\hline [49] & Security of tenure and land productivity in Kenya. & Kenya & NE \\
\hline [48] & $\begin{array}{l}\text { Productivity in Gambian Agriculture: A Generalized Probit } \\
\text { Analysis. }\end{array}$ & Gambia & SE \\
\hline [15] & $\begin{array}{l}\text { Indigenous Land Rights in Sub-Saharan Africa: } \\
\text { Appropriation, Security and Investment Demand. }\end{array}$ & Sub-Saharan Africa & SE \\
\hline [14] & $\begin{array}{l}\text { Designing Land Registration Systems for Developing } \\
\text { Countries. }\end{array}$ & International study & $\mathrm{NE}$ \\
\hline [40] & $\begin{array}{l}\text { The benefits of land registration and titling: Economic and } \\
\text { social perspectives. }\end{array}$ & International study & SE \\
\hline [16] & $\begin{array}{l}\text { Tenure security and productivity in small-scale agriculture } \\
\text { in Zimbabwe: Implications for South Africa. }\end{array}$ & Zimbabwe & SE \\
\hline [87] & $\begin{array}{l}\text { Land Tenure Security and Agricultural Performance in } \\
\text { Southern Africa. }\end{array}$ & Regional study & WE \\
\hline [57] & $\begin{array}{l}\text { Land Tenure and Food Security: A Review of Concepts, } \\
\text { Evidence, and Methods. }\end{array}$ & International study & NE \\
\hline [41] & $\begin{array}{l}\text { Land Tenure and Food Security: Exploring Dynamic } \\
\text { Linkages. }\end{array}$ & International study & $\mathrm{NE}$ \\
\hline [45] & African land tenure: Questioning basic assumptions. & Regional study & WE \\
\hline [11] & Land tenure and rural development. & International study & WE \\
\hline [64] & $\begin{array}{l}\text { Land tenure security and investment incentives: puzzling } \\
\text { evidence from Burkina Faso. }\end{array}$ & Burkina Faso & NE \\
\hline [90] & $\begin{array}{l}\text { Measuring and Analysing Agricultural Productivity in } \\
\text { Kenya: a Review of Approaches. }\end{array}$ & Kenya & WE \\
\hline [37] & $\begin{array}{l}\text { Sustainable land tenure and land registration in developing } \\
\text { countries, including a historical comparison with an } \\
\text { industrialised country. }\end{array}$ & International study & WE \\
\hline [19] & $\begin{array}{l}\text { Land Tenure, Fixed Investment, and Farm Productivity: } \\
\text { Evidence from Zambia s Southern Province. }\end{array}$ & Zambia & SE \\
\hline [66] & $\begin{array}{l}\text { Land Tenure Systems and their Impacts on Food Security } \\
\text { and Sustainable Development in Africa. }\end{array}$ & Regional study & WE \\
\hline [54] & $\begin{array}{l}\text { Investment and equity effects of land regularisation: the case } \\
\text { of Nicaragua. }\end{array}$ & Nicaragua & SE \\
\hline [55] & $\begin{array}{l}\text { Capital Creation, Transfer or Reversal; Assessing the } \\
\text { Outcomes of Systematic Demarcation of Customary Tenure } \\
\text { in Uganda. }\end{array}$ & Uganda & SE \\
\hline [91] & $\begin{array}{l}\text { Tenure security and land-related investment: Evidence from } \\
\text { Ethiopia. }\end{array}$ & Ethiopia & WE \\
\hline [70] & Improving tenure security for the rural poor. & Regional study & WE \\
\hline
\end{tabular}


Table A2. Cont.

\begin{tabular}{|c|c|c|c|}
\hline [36] & $\begin{array}{l}\text { The homogenization effect of land titling on investment } \\
\text { incentives: evidence from Peru. }\end{array}$ & Peru & $\mathrm{SE}$ \\
\hline$[65]$ & $\begin{array}{l}\text { The dynamics of tenure security, agricultural production } \\
\text { and environmental degradation in Africa: Evidence from } \\
\text { stakeholders in north-east Ghana. }\end{array}$ & Ghana & $\mathrm{SE}$ \\
\hline [92] & $\begin{array}{l}\text { Role of land tenure security and farm household } \\
\text { characteristics on land use change in the Prasae Watershed, } \\
\text { Thailand. }\end{array}$ & Thailand & $\mathrm{SE}$ \\
\hline [58] & $\begin{array}{l}\text { Rural Land Certification in Ethiopia: Process, Initial Impact, } \\
\text { and Implications. for Other African Countries. }\end{array}$ & Ethiopia & WE \\
\hline$[8]$ & $\begin{array}{l}\text { Impacts of Low-Cost Land Certification on Investment and } \\
\text { Productivity. }\end{array}$ & Ethiopia & SE \\
\hline [77] & $\begin{array}{l}\text { Land Tenure and Agricultural Productivity in Africa: A } \\
\text { Comparative Analysis of the Economics Literature and } \\
\text { Recent Policy Strategies and Reforms. }\end{array}$ & Regional study & WE \\
\hline [32] & $\begin{array}{l}\text { Land Tenure and Productivity: Farm-Level Evidence from } \\
\text { Papua New Guinea. }\end{array}$ & Papua New Guinea & SE \\
\hline$[30]$ & What tenure security? The case for a tripartite view. & International study & SE \\
\hline [88] & $\begin{array}{l}\text { Tenure security, formalization of rights, land regulation } \\
\text { institutions and investments. For a broader conceptual } \\
\text { framework. }\end{array}$ & International study & SE \\
\hline [34] & $\begin{array}{l}\text { Impacts of land certification on tenure security, investment, } \\
\text { and land market participation: Evidence from Ethiopia. }\end{array}$ & Ethiopia & SE \\
\hline [93] & The Future of Agriculture in Africa. & Regional study & WE \\
\hline$[43]$ & $\begin{array}{l}\text { Land tenure security, investments and the environment in } \\
\text { Ghana. }\end{array}$ & Ghana & SE \\
\hline$[31]$ & $\begin{array}{l}\text { Land tenure differences and investment in land } \\
\text { improvement measures: Theoretical and empirical analyses. }\end{array}$ & Ghana & WE \\
\hline [78] & $\begin{array}{l}\text { Land tenure and investment incentives: Evidence from West } \\
\text { Africa. }\end{array}$ & Regional study & WE \\
\hline$[63]$ & $\begin{array}{l}\text { The Productivity Impacts of Formal and Informal Land } \\
\text { Rights: Evidence from Madagascar. }\end{array}$ & Madagascar & WE \\
\hline [59] & $\begin{array}{l}\text { The Land Rights and Farm Investment Ghana: The Missing } \\
\text { Link in the Operationalisation of Tenure Security. }\end{array}$ & Ghana & WE \\
\hline [86] & $\begin{array}{l}\text { Land, power and peace: Tenure formalization, agricultural } \\
\text { reform, and livelihood insecurity in rural Rwanda. }\end{array}$ & Rwanda & WE \\
\hline [29] & $\begin{array}{l}\text { Evaluating the impact of Land Administration Programs on } \\
\text { agricultural productivity and rural development. }\end{array}$ & Latin America & WE \\
\hline [17] & Land administration for food security: A research synthesis. & International study & WE \\
\hline$[79]$ & $\begin{array}{l}\text { Assessing the role of policies on land use change and } \\
\text { agricultural development since 1960s in northern Ethiopia. } \\
\text { Land system change and food security: towards multi-scale }\end{array}$ & Ethiopia & $\mathrm{SE}$ \\
\hline$[94]$ & $\begin{array}{l}\text { land system solutions. Current Opinion in Environmental } \\
\text { Sustainability. }\end{array}$ & International study & WE \\
\hline [33] & $\begin{array}{l}\text { Agricultural Mechanization in Sub-Saharan Africa. } \\
\text { Guidelines for preparing a strategy. }\end{array}$ & Sub-Saharan Africa & SE \\
\hline$[60]$ & $\begin{array}{l}\text { The roles of land tenure reforms and land markets in the } \\
\text { context of population growth and land use intensification in } \\
\text { Africa. }\end{array}$ & Regional study & SE \\
\hline$[80]$ & $\begin{array}{l}\text { Trading-off: Rural food security and land rights in South } \\
\text { Africa. }\end{array}$ & South Africa & SE \\
\hline [52] & $\begin{array}{l}\text { The Impact of Land Property Rights Interventions on } \\
\text { Investment and Agricultural Productivity in Developing } \\
\text { Countries: a Systematic Review. }\end{array}$ & International study & WE \\
\hline [21] & $\begin{array}{l}\text { Land tenure security: revisiting and refining the concept for } \\
\text { Sub - Saharan Africa's rural poor. }\end{array}$ & Regional study & WE \\
\hline$[76]$ & $\begin{array}{l}\text { Environmental and gender impacts of land tenure } \\
\text { regularization in Africa: Pilot evidence from Rwanda. } \\
\text { Can Government-Allocated Land Contribute to Food }\end{array}$ & Rwanda & WE \\
\hline$[47]$ & $\begin{array}{l}\text { Security? Intrahousehold Analysis of West Bengal's } \\
\text { Microplot Allocation Program. } \\
\text { Does Smallholder Land Titling Facilitate Agricultural }\end{array}$ & India & SE \\
\hline [81] & $\begin{array}{l}\text { Growth?: An Analysis of the Determinants and Effects of } \\
\text { Smallholder and Titling in Zambia. }\end{array}$ & Zambia & $\mathrm{NE}$ \\
\hline [5] & $\begin{array}{l}\text { Land Tenure, Tenure Security and Farm Efficiency: Panel } \\
\text { Evidence from the Philippines. }\end{array}$ & Philippines & SE \\
\hline
\end{tabular}


Table A2. Cont.

\begin{tabular}{|c|c|c|c|}
\hline [53] & $\begin{array}{l}\text { Legitimate Land Tenure and Property Rights: Fostering } \\
\text { Compliance and Development Outcomes. }\end{array}$ & International study & SE \\
\hline [7] & $\begin{array}{l}\text { A policy paper on how land tenure systems and the } \\
\text { access/utilization of land could be addressed to facilitate } \\
\text { rural development in Africa. }\end{array}$ & Regional study & SE \\
\hline [56] & $\begin{array}{l}\text { Linking land governance and food security in Africa. } \\
\text { Outcomes from Uganda, Ghana \& Ethiopia. }\end{array}$ & Regional study & SE \\
\hline [42] & $\begin{array}{l}\text { Land tenure (in)security and crop-tree intercropping in rural } \\
\text { Xinjiang, China. }\end{array}$ & China & SE \\
\hline$[6]$ & $\begin{array}{l}\text { Land tenure reforms, tenure security and food security in } \\
\text { poor agrarian economies: Causal linkages and research gaps. }\end{array}$ & International study & WE \\
\hline [35] & $\begin{array}{l}\text { Can community-based land adjudication and registration } \\
\text { improve household land tenure security? Evidence from } \\
\text { Afghanistan. }\end{array}$ & Afghanistan & SE \\
\hline [51] & $\begin{array}{l}\text { A spatial explicit assessment of food security in Africa based } \\
\text { on simulated crop production and distribution. }\end{array}$ & Regional study & WE \\
\hline [3] & $\begin{array}{l}\text { Perceived land tenure security in rural Xinjiang, China: The } \\
\text { role of official land documents and trust. }\end{array}$ & China & NE \\
\hline [12] & $\begin{array}{l}\text { Land tenure insecurity in post-certification Amhara, } \\
\text { Ethiopia. }\end{array}$ & Ethiopia & $\mathrm{NE}$ \\
\hline [4] & $\begin{array}{l}\text { Land tenure security and technical efficiency: new insights } \\
28 \text { from a case study in Northwest China. }\end{array}$ & China & SE \\
\hline [28] & $\begin{array}{l}\text { Drivers of perceived land tenure (in)security: Empirical } \\
\text { evidence from Ghana. }\end{array}$ & Ghana & WE \\
\hline [10] & $\begin{array}{l}\text { Cadastre: Geo-Information Innovations in Land } \\
\text { Administration. }\end{array}$ & International study & SE \\
\hline [89] & $\begin{array}{l}\text { New Ways to Assess and Enhance Land Registry } \\
\text { Sustainability: Evidence from Rwanda }\end{array}$ & Rwanda & SE \\
\hline [73] & Working with Smallholders. & International study & SE \\
\hline [1] & $\begin{array}{l}\text { Investigating the impacts of increased rural land tenure } \\
\text { security: A systematic review of the evidence. }\end{array}$ & International study & SE \\
\hline [44] & $\begin{array}{l}\text { Formalization without certification? Experimental evidence } \\
\text { on property rights and investment. }\end{array}$ & Benin & SE \\
\hline [61] & $\begin{array}{l}\text { Too small to be beautiful? The farm size and productivity } \\
\text { relationship in Bangladesh. }\end{array}$ & Bangladesh & SE \\
\hline [2] & $\begin{array}{l}\text { Land tenure security and investment: Does strength of land } \\
\text { right really matter in rural Burkina Faso? }\end{array}$ & Burkina Faso & $\mathrm{SE}$ \\
\hline [67] & $\begin{array}{l}\text { Collateral: The Sword of Damocles of the Small-scale } \\
\text { Farmers; Land Tenure Issues in Africa. }\end{array}$ & Regional study & SE \\
\hline [62] & $\begin{array}{l}\text { The Role of Land Use Consolidation in Improving Crop } \\
\text { Yields among Farm Households in Rwanda. }\end{array}$ & Rwanda & WE \\
\hline [83] & $\begin{array}{l}\text { Land tenure security and adoption of modern rice } \\
\text { technology in Odisha, Eastern India: Revisiting Besley's } \\
\text { hypothesis. }\end{array}$ & India & SE \\
\hline [72] & $\begin{array}{l}\text { Why Tenure Responsive Land-Use Planning Matters: } \\
\text { Insights for Land Use Consolidation for Food Security in } \\
\text { Rwanda. }\end{array}$ & Rwanda & SE \\
\hline [71] & $\begin{array}{l}\text { Women's land rights as a pathway to poverty reduction: } \\
\text { Framework and review of available evidence. }\end{array}$ & International study & WE \\
\hline [74] & $\begin{array}{l}\text { The role of land tenure security in promoting rural women's } \\
\text { empowerment: Empirical evidence from rural China. }\end{array}$ & China & SE \\
\hline [75] & $\begin{array}{l}\text { Sustaining land registration benefits by addressing the } \\
\text { challenges of reversion to informality in Rwanda. }\end{array}$ & Rwanda & SE \\
\hline [84] & $\begin{array}{l}\text { Decisions by Chinese households regarding renting in arable } \\
\text { land-The impact of tenure security perceptions and trust. }\end{array}$ & China & $\mathrm{SE}$ \\
\hline [20] & $\begin{array}{l}\text { Linking land tenure security with food security: Unpacking } \\
\text { farm households' perceptions and strategies in the rural } \\
\text { uplands of Laos. }\end{array}$ & Laos & $\mathrm{SE}$ \\
\hline
\end{tabular}

SE: strong evidence; WE: weak evidence; NE: no evidence.

\section{References}

1. Abdulai, A.; Owusu, V.; Goetz, R. Land tenure differences and investment in land improvement measures: Theoretical and empirical analyses. J. Dev. Econ. 2011, 9666-9678. [CrossRef]

2. Ali, D.A.; Deininger, K.; Duponchel, M. New ways to assess and enhance land registry sustainability: Evidence from Rwanda. World Dev. 2017, 99, 377-394. [CrossRef] 
3. Ali, D.A.; Deininger, K.; Goldstein, M. Environmental and gender impacts of land tenure regularization in Africa: Pilot evidence from Rwanda. J. Dev. Econ. 2014, 110, 262-275. [CrossRef]

4. Ali, D.A.; Deininger, K.; Mahofa, G.; Nyakulama, R. Sustaining land registration benefits by addressing the challenges of reversion to informality in Rwanda. Land Use Policy 2019, 104317. [CrossRef]

5. Alston, L.; Mueller, B. Towards a more evolutionary theory of property rights. Iowa Law Rev. 2015, 100, 2255-2273.

6. Atwood, D.A. Land registration in Africa: The impact on agricultural production. World Dev. 1990, 18659-18671. [CrossRef]

7. Ayamga, M.; Dzanku, F. The land rights and farm. investment ghana: The missing link in the operationalisation of tenure security. In Proceedings of the 4th International Conference of the African Association of Agricultural Economists, Hammamet, Tunisia, 22-25 September 2013.

8. Baltissen, G.; Betsema, G. Linking Land Governance and Food Security in Africa. Outcomes from Uganda, Ghana, Ethiopia. 2016. Available online: https://www.landgovernance.org/assets/20160831-LANDac_Reflectionpaper1.pdf (accessed on 21 December 2019).

9. Bambio, Y.; Agha, B.S. Land tenure security and investment: Does strength of land right really matter in rural Burkina Faso? World Dev. 2018, 111, 130-147. [CrossRef]

10. Barrows, R.; Roth, M. Land tenure and investment in African agriculture: Theory and evidence. J. Mod. Afr. Stud. 1990, 28, 265-297. [CrossRef]

11. Bellemare, M.F. The productivity impacts of formal and informal land rights: Evidence from Madagascar. Land Econ. 2013, 89, 19. [CrossRef]

12. Boboya, J. A policy paper on how land tenure systems and the access/utilization of land could be addressed to facilitate rural development in Africa. J. Mod. Afr. Stud. 2015, 28, 265-297.

13. Brasselle, A.-S.; Gaspart, F.; Platteau, J.-P. Land tenure security and investment incentives: Puzzling evidence from Burkina Faso. J. Dev. Econ. 2002, 67, 373-418. [CrossRef]

14. Bugri, J.T. The dynamics of tenure security, agricultural production and environmental degradation in Africa: Evidence from stakeholders in north-east Ghana. Land Use Policy 2008, 25, 271-285. [CrossRef]

15. Chand, S.; Yala, C. Land tenure and productivity: Farm-level evidence from Papua New Guinea. Land Econ. 2009, 85, 442-453. [CrossRef]

16. Chigbu, U.E.; Ntihinyurwa, P.D.; de Vries, W.T.; Ngenzi, E.I. Why tenure responsive land-use planning matters: Insights for land use consolidation for food security in Rwanda. Int. J. Environ. Res. Public Health 2019, 16, 1354. [CrossRef]

17. Cooper, H.M. Synthesizing Research: A Guide for Literature Reviews, 3rd ed.; Cooper, H.M., Ed.; Sage Publications: Thousand Oaks, CA, USA, 1998.

18. Deininger, K.; Ali, D.A.; Alemu, T. Impacts of land certification on tenure security, investment, and land market participation: Evidence from Ethiopia. Land Econ. 2011, 87, 312-334. [CrossRef]

19. Deininger, K.; Ali, D.A.; Holden, S.; Zevenbergen, J. Rural land certification in Ethiopia: Process, initial impact, and implications for other African countries. World Dev. 2008, 36, 1786-1812. [CrossRef]

20. Deininger, K.; Chamorro, J.S. Investment and equity effects of land regularisation: The case of Nicaragua. Agric. Econ. 2004, 30, 101-116. [CrossRef]

21. Deininger, K.; Jin, S. Tenure security and land-related investment: Evidence from Ethiopia. Eur. Econ. Rev. 2006, 50, 1245-1277. [CrossRef]

22. ECA/SDD. Land Tenure Systems and Their Impacts on Food Security and Sustainable Development in Africa; Economic Commission for Africa's Sustainable Development Division (SDD): Addis Ababa, Ethiopia, 2004.

23. Ege, S. Land tenure insecurity in post-certification Amhara, Ethiopia. Land Use Policy 2017, 64, 56-63. [CrossRef]

24. FAO. Land Tenure and Rural Development; Food and Agriculture Organization of the United Nations: Rome, Italy, 2002.

25. FAO. Agricultural Mechanization in Sub-Saharan Africa. Guidelines for preparing a strategy; Integrated Crop Management: Rome, Italy, 2013; Volume 22.

26. Feder, G.; Nishio, A. The benefits of land registration and titling: Economic and social perspectives. Land Use Policy 1998, 15, 25-43. [CrossRef]

27. Feder, G.; Noronha, R. Land rights systems and agricultural development in sub-saharan Africa. World Bank Res. Obs. 1987, 2, 143-169. [CrossRef] 
28. Feder, G.; Onchan, T.; Hongladarom, C.; Chalamwong, Y.; Feder, G.; Onchan, T.; Chalamwong, Y. Land Policies and Farm Productivity in Thailand; Johns Hopkins University Press: Baltimore, MD, USA, 1988.

29. Fenske, J. Land tenure and investment incentives: Evidence from west Africa. J. Dev. Econ. 2011, 95, 13-156. [CrossRef]

30. Fort, R. The homogenization effect of land titling on investment incentives: Evidence from Peru. Njas Wagening. J. Life Sci. 2008, 55, 325-343. [CrossRef]

31. Gautam, M.; Ahmed, M. Too small to be beautiful? The farm size and productivity relationship in Bangladesh. Food Policy 2018. [CrossRef]

32. Ghebru, H.; Lambrecht, I. Drivers of perceived land tenure (in)security: Empirical evidence from Ghana. Land Use Policy 2017, 66, 293-303. [CrossRef]

33. Gignoux, J.; Macours, K.; Wren-Lewis, L. Evaluating the Impact of Land Administration Programs on Agricultural Productivity and Rural Development; Inter-American Development Bank (IDB): Washington, DC, USA, 2013.

34. Goldstein, M.; Houngbedji, K.; Kondylis, F.; O'Sullivan, M.; Selod, H. Formalization without certification? Experimental evidence on property rights and investment. J. Dev. Econ. 2018, 132, 57-74. [CrossRef]

35. Han, W.; Zhang, X.; Zhang, Z. The role of land tenure security in promoting rural women's empowerment: Empirical evidence from rural China. Land Use Policy 2019, 86, 280-289. [CrossRef]

36. Hanstad, T. Designing land registration systems for developing countries. Am. Univ. Int. Law Rev. 1998, 13, 56.

37. Hart, C. Doing a Literature Review: Releasing the Social Science Research Imagination; Sage: London, UK, 2007.

38. Hayes, J.; Roth, M.; Zepeda, L. Tenure security, investment and productivity in gambian agriculture: A generalized probit analysis. Am. J. Agric. Econ. 1997, 79, 369-382. [CrossRef]

39. Higgins, D.; Balint, T.; Liversage, H.; Winters, P. Investigating the impacts of increased rural land tenure security: A systematic review of the evidence. J. Rural Stud. 2018, 61, 34-62. [CrossRef]

40. Holden, S.T.; Deininger, K.; Ghebru, H. Impacts of low-cost land certification on investment and productivity. Am. J. Agric. Econ. 2009, 91, 359-373. [CrossRef]

41. Holden, S.T.; Ghebru, H. Land tenure reforms, tenure security and food security in poor agrarian economies: Causal linkages and research gaps. Glob. Food Secur. 2016, 10, 21-28. [CrossRef]

42. Holden, S.T.; Otsuka, K. The roles of land tenure reforms and land markets in the context of population growth and land use intensification in Africa. Food Policy 2014, 48, 88-97. [CrossRef]

43. Kamusiime, H.; Rugadya, M.; Obaikol, E. Capital Creation, Transfer or Reversal; Assessing the Outcomes of Systematic Demarcation of Customary Tenure in Uganda; Land Research Series: Kampala, Uganda, 2005; Volume 6.

44. Kariuki, J.G. The Future of Agriculture in Africa; The Pardee Papers; Boston University: Boston, MA, USA, 2011; Volume 15.

45. Keovilignavong, O.; Suhardiman, D. Linking land tenure security with food security: Unpacking farm households' perceptions and strategies in the rural uplands of Laos. Land Use Policy 2019, 90, 104260. [CrossRef]

46. Kepe, T.; Tessaro, D. Trading-off: Rural food security and land rights in South Africa. Land Use Policy 2014, 36, 267-274. [CrossRef]

47. Krier, J. Evolutionary theory and the origin of property rights. Cornell Law Rev. 2009, 95, 139.

48. Kunz, Y.; Hein, J.; Mardiana, R.; Faust, H. Mimicry of the legal: Translating de jure land formalization processes into de facto local action in jambi province, Sumatra. Austrian J. South. East. Asian Stud. 2016, 9, 127-146. [CrossRef]

49. Delville, L.P. Tenure security, formalization of rights, land regulation institutions and investments. For a broader conceptual framework. Land Tenure J. 2010, 1, 5-33.

50. Lawin, G.; Tamini, L. Tenure security and farm efficiency analysis correcting for biases from observed and unobserved variables: Evidence from benin. J. Agric. Econ. 2017, 70. [CrossRef]

51. Lawry, S.; Samii, C.; Hall, R.; Leopold, A.; Hornby, D.; Mtero, F. The impact of land property rights interventions on investment and agricultural productivity in developing countries: A systematic review. J. Dev. Eff. 2017, 9, 61-81. [CrossRef]

52. Lemel, H. Land titling: Conceptual, empirical and policy issues. Land Use Policy 1988, 5, 273-290. [CrossRef]

53. Li, H.; Zhang, X. A spatial explicit assessment of food security in Africa based on simulated crop production and distribution. J. Clean. Prod. 2017, 147, 628-636. [CrossRef] 
54. Lund, C. African Land Tenure: Questioning Basic Assumptions; International Institute For Environment and Development: London, UK, 2000.

55. Lund, C.; Rachman, N. Occupied! Property, citizenship and peasant movements in rural java: Property, citizenship and peasant movements in java. Dev. Chang. 2016, 47, 1316-1337. [CrossRef]

56. Ma, X.; Heerink, N.; Feng, S.; Shi, X. Land tenure security and technical efficiency: New insights from a case study in northwest China. Environ. Dev. Econ. 2017, 23, 305-327. [CrossRef]

57. Ma, X.; Heerink, N.; van Ierland, E.; Lang, H.; Shi, X. Decisions by Chinese households regarding renting in arable land-The impact of tenure security perceptions and trust. China Econ. Rev. 2019, 101328. [CrossRef]

58. Maxwell, D.; Wiebe, K. Land tenure and food security: Exploring dynamic linkages. Dev. Chang. 1999, 30, 825-849. [CrossRef]

59. Maxwell, D.G.; Wiebe, K.D. Land Tenure and Food Security: A Review of Concepts, Evidence, and Methods. 1998. Available online: http://ageconsearch.umn.edu/record/12752/files/ltcrp129.pdf (accessed on 3 January 2020).

60. Meinzen-Dick, R.; Quisumbing, A.; Doss, C.; Theis, S. Women's land rights as a pathway to poverty reduction: Framework and review of available evidence. Agric. Syst. 2019, 172, 72-82. [CrossRef]

61. Michler, J.D.; Shively, G.E. Land tenure, tenure security and farm efficiency: Panel evidence from the Philippines. J. Agric. Econ. 2015, 66, 155-169. [CrossRef]

62. Migot-Adholla, S.E.; Place, F.; Oluoch-Kosura, W. Security of Tenure and Land Productivity in Kenya; Department of Agricultural Economics: Nairobi, Kenya, 1994.

63. Migot, A.; Peter, H.; Benoît, B.; Frank, P. Indigenous land rights systems in sub-saharan Africa: A constraint on productivity? World Bank Econ. Rev. 1991, 5. [CrossRef]

64. Moor, G.M.; Nieuwoudt, W.L. Tenure security and productivity in small-scale agriculture in Zimbabwe: Implications for South Africa. Dev. South. Afr. 1998, 15, 609-620. [CrossRef]

65. Murtazashvili, I.; Murtazashvili, J. Can community-based land adjudication and registration improve household land tenure security? Evidence from Afghanistan. Land Use Policy 2016, 55, 230-239. [CrossRef]

66. Ncube, D. Collateral: The sword of damocles of the small-scale farmers; land tenure issues in Africa. Open Agric. J. 2018, 12, 46-63. [CrossRef]

67. Nilsson, P. The role of land use consolidation in improving crop yields among farm households in Rwanda. J. Dev. Stud. 2018. [CrossRef]

68. Odhiambo, W. Improving Tenure Security for the Rural Poor; LEP Working Paper 3; FAO: Rome, Italy, 2006.

69. Odhiambo, W. Measuring and Analysing Agricultural Productivity in Kenya: A Review of Approaches; Nyangito, H., Ed.; Kenya Institute for Public Policy Research and Analysis: Nairobi, Kenya, 2003.

70. Paltasingh, K.R. Land tenure security and adoption of modern rice technology in Odisha, eastern India: Revisiting Besley's hypothesis. Land Use Policy 2018, 78, 236-244. [CrossRef]

71. Payne, G.; Mitchell, J.; Kozumbo, L.; English, C.; Baldwin, R. Legitimate Land Tenure and Property Rights: Fostering Compliance and Development Outcomes. 2015. Available online: https://assets.publishing.service. gov.uk/media/57a0896ded915d622c0001f9/61566-REA-Land-Q2publish.pdf (accessed on 3 January 2019).

72. Place, F. Land tenure and agricultural productivity in Africa: A comparative analysis of the economics literature and recent policy strategies and reforms. World Dev. 2009, 37, 1326-1336. [CrossRef]

73. Place, F.; Hazell, P. Productivity effects of indigenous land tenure systems in sub-saharan Africa. Am. J. Agric. Econ. 1993, 75, 10-19. [CrossRef]

74. Place, F.; Roth, M.; Hazell, P. Land Tenure Security and Agricultural Performance in Africa: Overview of Research Methodology. 1994. Available online: https://pdfs.semanticscholar.org/8840/0e079dd37f3f72de5ba9dd03acce1e9e25b2. pdf (accessed on 14 May 2019).

75. Platteau, J.-P. The evolutionary theory of land rights as applied to sub-saharan Africa: A critical assessment. Dev. Chang. 2008, 27, 29-86. [CrossRef]

76. Popay, J.; Roberts, H.; Sowden, A.; Petticrew, M.; Arai, L.; Rodgers, M.; Duffy, S. Guidance on the Conduct of Narrative Synthesis in Systematic Reviews: A Product from the Esrc Methods Programme; Lancaster University: Lancaster, UK, 2006.

77. Pritchard, M.F. Land, power and peace: Tenure formalization, agricultural reform, and livelihood insecurity in rural Rwanda. Land Use Policy 2013, 30, 186-196. [CrossRef]

78. Rao, F.; Spoor, M.; Ma, X.; Shi, X. Land tenure (in)security and crop-tree intercropping in rural Xinjiang, China. Land Use Policy 2016, 50, 102-114. [CrossRef] 
79. Rao, F.; Spoor, M.; Ma, X.; Shi, X. Perceived land tenure security in rural Xinjiang, China: The role of official land documents and trust. China Econ. Rev. 2017. [CrossRef]

80. Rockson, G.; Bennett, R.; Groenendijk, L. Land administration for food security: A research synthesis. Land Use Policy 2013, 32, 337-342. [CrossRef]

81. Roth, M.; Haase, D. Land Tenure Security and Agricultural Performance in Southern Africa. 1998. Available online: http://citeseerx.ist.psu.edu/viewdoc/download?doi=10.1.1.465.647\&rep=rep1\&type=pdf (accessed on 12 April 2019).

82. Santos, F.; Fletschner, D.; Savath, V.; Peterman, A. Can government-allocated land contribute to food security? Intrahousehold analysis of west bengal's microplot allocation program. World Dev. 2014, 64, 860-872. [CrossRef]

83. Simbizi, M.C.D.; Bennett, R.M.; Zevenbergen, J. Land tenure security: Revisiting and refining the concept for Sub-Saharan Africa's rural poor. Land Use Policy 2014, 36, 231-238. [CrossRef]

84. Sitko, N.J.; Chamberlin, J.; Hichaambwa, M. Does smallholder land titling facilitate agricultural growth?: An analysis of the determinants and effects of smallholder land titling in Zambia. World Dev. 2014, 64, 791-802. [CrossRef]

85. Sjaastad, E.; Bromley, D.W. Indigenous land rights in sub-saharan Africa: Appropriation, security and investment demand. World Dev. 1997, 25, 549-562. [CrossRef]

86. Smith, R.E. Land tenure, fixed investment, and farm productivity: Evidence from Zambia's Southern province. World Dev. 2004, 32, 1641-1661. [CrossRef]

87. Tahsin, Y.; McLaughlin, J. Cadastre: Geo-Information Innovations in Land Administration; Springer International Publishing: Cham, Switzerland, 2017.

88. Teka, K.; Van Rompaey, A.; Poesen, J. Assessing the role of policies on land use change and agricultural development since 1960s in Northern Ethiopia. Land Use Policy 2013, 30, 944-951. [CrossRef]

89. Törhönen, M.-P. Sustainable land tenure and land registration in developing countries, including a historical comparison with an industrialised country. Comput. Environ. Urban. Syst. 2004, 28, 545-586. [CrossRef]

90. Twerefou, D.; Osei-Assibey, E.; Agyire-Tettey, F. Land tenure security, investments and the environment in Ghana. J. Dev. Agric. Econ. 2011, 3, 261-273.

91. Van Gelder, J.-L. What tenure security? The case for a tripartite view. Land Use Policy 2010, 2, 7449-7456. [CrossRef]

92. Verburg, P.H.; Mertz, O.; Erb, K.-H.; Haberl, H.; Wu, W. Land system change and food security: Towards multi-scale land system solutions. Curr. Opin. Environ. Sustain. 2013, 5, 494-502. [CrossRef] [PubMed]

93. Wannasai, N.; Shrestha, R.P. Role of land tenure security and farm household characteristics on land use change in the prasae watershed, Thailand. Land Use Policy 2008, 25, 214-224. [CrossRef]

94. World Bank. Working with Smallholders: A Handbook for Firms Building Sustainable Supply Chains; International Finance Corporation: Washington, DC, USA, 2018. 